\title{
Tarefa virtual associada a estimulação transcraniana por corrente contínua em pessoas com doença de Parkinson
}

\author{
Virtual task associated with transcranial \\ stimulation by continuing the current in \\ people with Parkinson's disease
}

\author{
Joyce Alves de Lima' (1) \\ Amanda Oramos Simcsik ${ }^{2}$ (1) \\ Flavia Datte Rodrigues ${ }^{3}$ (C) \\ Rodrigo Daminello Raimundo 4 (1)
}

\author{
Ricardo Galhardoni ${ }^{5}$ (1) \\ Carlos Bandeira de Mello Monteiro 6 (1) \\ Talita Dias da Silva7 ${ }^{7}$
}

\begin{abstract}
'Autora para correspondência. Escola de Artes, Ciências e Humanidades da Universidade de São Paulo (São Paulo), São Paulo, Brasil. joycealves.fisio@yahoo.com.br

2,3,6Escola de Artes, Ciências e Humanidades da Universidade de São Paulo (São Paulo), São Paulo, Brasil. amanda.simcsik11@gmail.com, flavia.datte12@gmail.com, carlosmonteiro@usp.br ${ }^{4}$ Centro Universitário - Fundação do ABC (Santo André). São Paulo, Brasil. rodrigo.raimundo@fmabc.br ${ }^{5}$ Departamento de Neurologia do Hospital das Clínicas - Faculdade de Medicina da Universidade de São Paulo (São Paulo), São Paulo, Brasil. rgalhardoni@gmail.com 7Universidade Federal de São Paulo (São Paulo), São Paulo, Brasil. brasilft.talitadias@gmail.com
\end{abstract}

RESUMO | INTRODUÇÃO: Doença de Parkinson (DP) é uma doença crônica e degenerativa do sistema nervoso central, que ocorre pela morte de neurônios motores da substância negra, diminuindo a dopamina. Os distúrbios motores mais encontrados são bradicinesia, hipocinesia, acinesia, tremor, rigidez, alterações de equilíbrio e marcha, além de dor e fadiga, limitando a execução de atividades cotidianas ${ }^{1}$. A ação da Estimulação Transcraniana por Corrente Contínua (ETCC) se dá através das mudanças nas taxas de disparo neuronal espontâneo, plasticidade sináptica e não-sináptica e mudanças na polarização de repouso dos neurônios, desencadeando neuroplasticidade em áreas corticais criticamente envolvidas no desempenho das tarefas, levando a melhora da resposta funcional de forma não-invasiva² ${ }^{2}$. A utilização da realidade virtual $(\mathrm{RV})$ na reabilitação se baseia no uso de jogos e tarefas em ambientes virtuais para estimular funções físicas e cognitivas em pessoas com diferentes tipos de deficiências sem grandes demandas de espaço físico e equipamentos ${ }^{3}$. Com a variedade de disfunções motoras, o déficit de alternativas de tratamentos e espaços adaptados para essas pessoas, tornaram-se necessárias alternativas que supram essas lacunas, evidenciando a possibilidade de intervenções terapêuticas mistas por meio da RV e de ETCC, possibilitando a estimulação de membros inferiores (MMII) de forma funcional, prazerosa, segura e capazes de oferecer dados de desempenho das pessoas com DP. OBJETIVOS: Avaliar o desempenho motor de MMII em tarefas virtuais por meio da quantidade de perdas e acertos ao alvo em pessoas com DP associado ao uso de Estimulação Transcraniana por Corrente Contínua (ETCC). MATERIAIS E MÉTODOS: Este projeto foi aprovado pelo comitê de ética CAAE:02908218.0.0000.5390, registrado 
no Clinical Trials: NCT04527809. Este foi um Estudo Transversal usando um desenho randomizado, duplocego onde foram incluídas pessoas com diagnóstico de DP de ambos os sexos e excluídas pessoas que não fossem capazes de ficar em pé de forma independente e com patologias neurológicas associadas. Em única sessão, os participantes foram avaliados pelo software MoveHero, um jogo com bolas que caem em duas colunas imaginárias na tela, no ritmo de uma música escolhida pelo pesquisador. As bolas devem ser tocadas quando alcançarem quatro círculos colocados de forma paralela, em dois níveis de altura, a uma distância de um metro e meio da tela, juntamente com a ETCC, ferramenta não-invasiva, indolor, que através de corrente elétrica é capaz de modular o sistema dopaminérgico e a excitabilidade cortical, utilizando-se de dois eletrodos, aumentando (anódica) ou diminuindo-a (catódica) com intensidade de $2 \mathrm{~mA}$, rampa=20 s (subida=10 s; descida=10 s) no Grupo Ativo (GA) e uma rampa única com duração=30 s no Grupo Sham (GS), tendo o eletrodo ânodo fixado em M1 (córtex motor primário) e o cátodo fixado na região supraorbital contralateral na área durante 20 minutos em ambos os grupos. Como variáveis dependentes do MoveHero, foram consideradas a quantidade de acertos, perdas e antecipações ao alvo. As tentativas de acerto em cada posição (Esquerda e Direita) no MoveHero foram divididas por dois, e assim transformadas em dois blocos de tentativas para avaliar a melhora das tentativas iniciais para as finais da jogada. Para comparação entre GS e GA foi utilizado o teste-t e para medidas repetidas para o fator Blocos e Posição da bola (Direita e Esquerda) foi utilizado o teste-t pareado. RESULTADOS: Foram avaliadas 55 pessoas, divididas aleatóriamente em 2 grupossendo 26 no GA com $62,2 \pm 11$,1anos, e 29 no GS com 66,3 $\pm 7,2$ anos, pontuação na Escala Unificada de Classificação da Doença de Parkinson (UPDRS) na Parte Exame Motor GA 10,7 $\pm 6,3$ e GS 14,2 $\pm 6,3$ ( $p=$ 0,04), na Parte Complicações e Discinesias GA 1,2 $\pm 1,4$ e GS $2,3 \pm 1,9(p=0,02)$ e na Parte Outras Complicações GA $0,6 \pm 0,6$ e GS $1,0 \pm 0,8(p=0,05)$. Foram encontrados efeitos para Blocos no Erro Absoluto (que representa acurácia de movimento) entre o Bloco $1(331,3 \pm 200,8)$ e o Bloco $2(493,0 \pm 347,3)$ à Esquerda no $G A(p=0,005$, Cohens' $d=0.43$ ), e para Grupos no Erro Absoluto

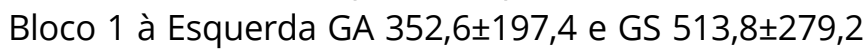

$(p=0,018$, Cohens $d=0.63$ ) e no Erro Variável (que representa a precisão de movimento) Bloco 2 à Esquerda GA $358,0 \pm 251,3$ e GS 523,0 $\pm 257,2$ ( $p=0,035$, Cohens' $d=0.64$ ) do $G A$, sem efeitos ou interações para Acertos com relação a Grupos, Blocos ou Posição da bola. Este resultado mostra que o grupo Sham apresentou uma quantidade muito maior de bolas perdidas (Erros e Antecipações) no jogo do que o grupo Ativo, corroborando com Conceição", onde a ETCC anódica ativa no córtex pré-frontal promoveu benefícios superiores aos de uma sessão de placeboo na atividade cortical, cognição e andar de pacientes com DP.
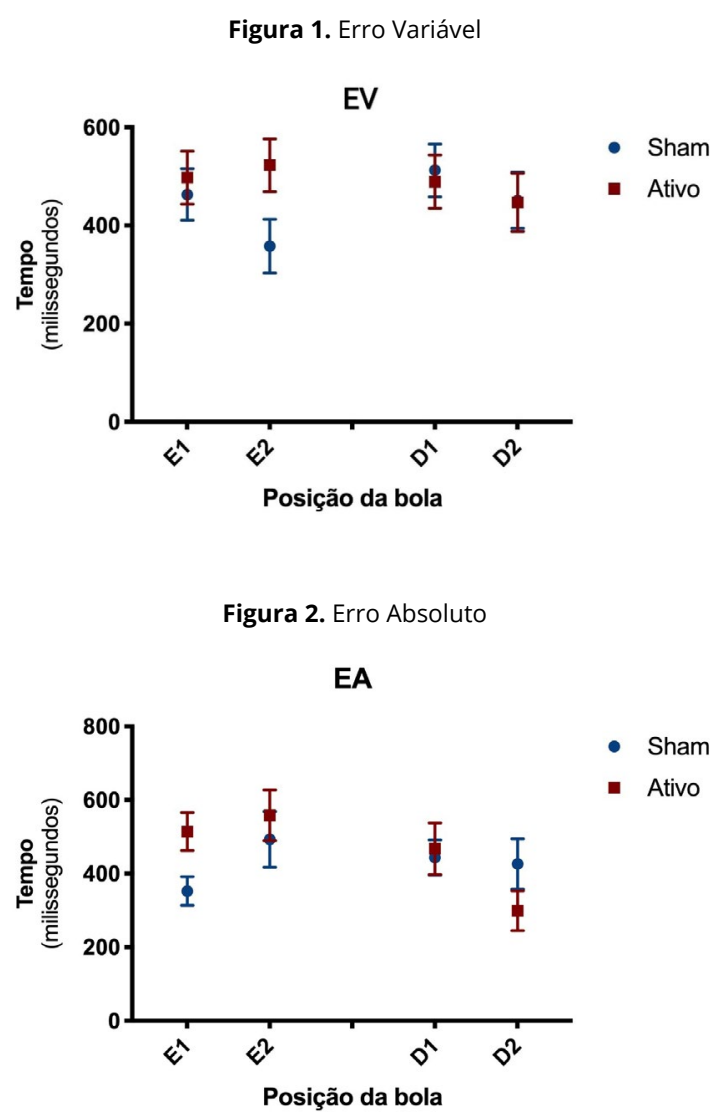

CONCLUSÃO: As pessoas que fizeram ETCC ativa apresentaram melhor desempenho observado por melhor acurácia (erro absoluto) e precisão (erro variável) de movimento.

PALAVRAS-CHAVE: Terapia de Exposição à Realidade Virtual. Estimulação Transcraniana por Corrente Contínua. Doença de Parkinson. Destreza Motora. 
ABSTRACT | INTRODUCTION: Parkinson's disease (PD) is a chronic and degenerative disease of the central nervous system due to the death of motor neurons of the substantia nigra, decreasing dopamine. The most common motor disorders are bradykinesia, hypokinesia, akinesia, tremor, stiffness, changes in balance and gait, in addition to pain and fatigue limiting the execution of daily activities $^{1}$. The action of Transcranial Direct Current Stimulation (ETCC) occurs through changes in rates of spontaneous neuronal firing, synaptic and non-synaptic plasticity, and changes in the resting polarization of neurons, triggering neuroplasticity in cortical areas critically involved in the performance of tasks, leading to an improved non-invasive functional response ${ }^{2}$. The use of virtual reality (VR) in rehabilitation is based on the use of games and tasks in virtual environments to stimulate physical and cognitive functions in people with different types of disabilities without great demands for physical space and equipment ${ }^{3}$. With the variety of motor dysfunctions, the alternatives of treatments and spaces adapted for these people became necessary the alternatives that fill these gaps, showing the possibility of mixed therapeutic interventions through VR and ETCC, enabling the stimulation of lower limbs (lower limbs) in a functional, pleasant, safe and capable of offering performance data for people with PD. OBJECTIVES: To assess the motor performance of lower limbs in virtual tasks through the number of losses and hits to the target in people with PD associated with the use of Transcranial Direct Current Stimulation (ETCC). MATERIALS AND METHODS: The CAAE ethics committee approved this project: 02908218.0.0000.5390, registered in the Clinical Trials: NCT04527809. That was a CrossSectional Study using a randomized, double-blind design that included people diagnosed with PD of both sexes and excluded people who were not able to stand independently and with associated neurological pathologies. In a single session, participants were evaluated by the MoveHero software, a game with balls that fall into two imaginary columns on the screen, in the rhythm of a song chosen by the researcher. The balls should be touched when they reached four circles placed in parallel, on two levels of height, at a distance of one and a half meters from the screen, together with the ETCC.
This non-invasive, painless tool through electrical current is capable of modulating the dopaminergic system and cortical excitability, using two electrodes, increasing (anodic) or decreasing (cathodic) with an intensity of $2 \mathrm{~mA}$, ramp $=20 \mathrm{~s}$ (rise $=10 \mathrm{~s}$; descent $=10 \mathrm{~s}$ ) at Active Group (GA) and a single ramp with duration $=30$ sin the Sham Group (GS), with the anode electrode fixed in M1 (primary motor cortex) and the cathode fixed in the contralateral supraorbital region in the area for 20 minutes in both groups. As variables dependent on MoveHero, the number of hits, losses, and anticipations to the target were considered. The hit attempts in each position (Left and Right) on MoveHero were divided by two and thus transformed into two blocks of attempts to assess the initial attempts' improvement for the end of the movement. For comparison between GS and $\mathrm{GA}$, the t-test was used, and for repeated measures for the Blocks and Ball Position factor (Right and Left), the paired t-test was used. RESULTS: 55 people were evaluated, randomly divided into 2 groups, 26 in GA with $62.2 \pm 11.1$ years, and 29 in GS with $66.3 \pm 7.2$ years, with a score on the Unified Parkinson's Disease Classification Scale (UPDRS) in the Exame Motor Part GA $10.7 \pm 6.3$ and GS $14.2 \pm$ $6.3(p=0.04)$, in the Complications and Dyskinesias Part GA $1.2 \pm 1.4$ and GS $2.3 \pm 1.9(p=0.02)$ and in the Other Complications Part GA $0.6 \pm 0.6$ and GS $1.0 \pm 0.8(p=0.05)$. Effects were found for Blocks in Absolute Error (which represents movement accuracy) between Block 1 (331.3 \pm 200.8) and Block $2(493.0 \pm 347.3)$ on the left in $\mathrm{GA}(p=0.005$, Cohens ' $d=0.43$ ), and for Groups in Absolute Error Block 1 on the Left GA $352.6 \pm 197.4$ and GS 513.8 $\pm 279.2(p=0.018$, Cohens' $d=0.63)$ and in Variable Error ( representing the precision of movement) Block 2 on the Left GA $358.0 \pm 251.3$ and GS 523.0 $\pm 257.2(p=0.035$, Cohens' $d=0.64)$ of the GA, without effects or interactions for hits with respect a Groups, Blocks or Position of the ball. This result shows that the Sham group presented a much larger number of lost balls (Errors and Anticipations) in the game than the Active group, corroborating with Conceição ${ }^{4}$, where the anodic ETCC active in the prefrontal cortex promoted benefits superior to those of a session of placebo in cortical activity, cognition and walking in PD patients. 
Figure 1. Variable Error

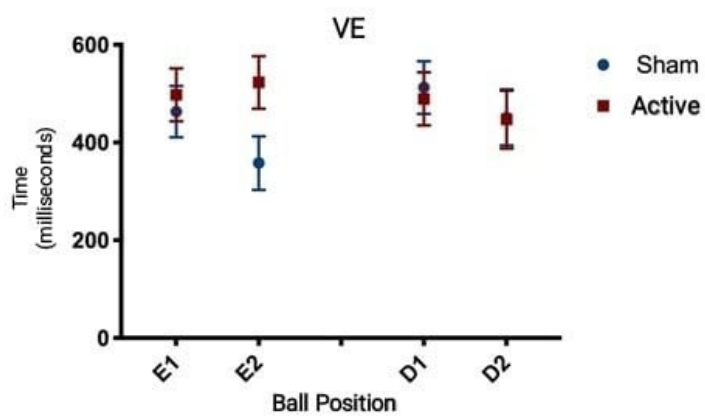

Figure 2. Absolut Error

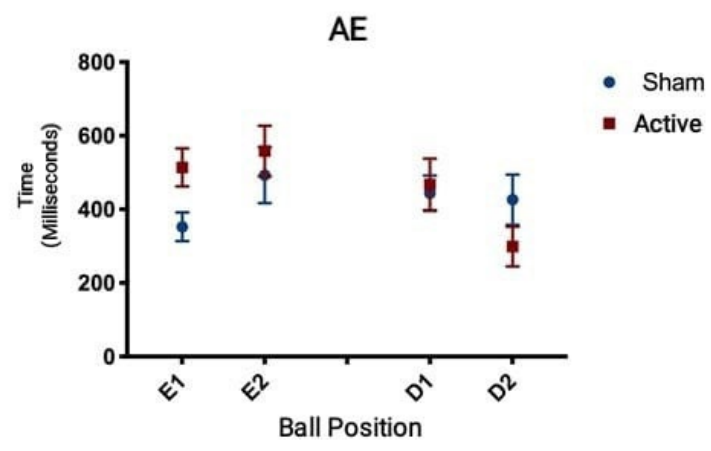

CONCLUSION: People who had active ETCC showed better performance, observed for better accuracy (absolute error) and precision (variable error) of movement.

KEYWORDS: Virtual Reality Exposure Therapy. Transcranial direct current stimulation. Parkinson's disease. Motor Dexterity.

\section{Contribuições dos autores}

Lima JA, Simcsik AO e Rodrigues FD conduziram a coleta de dados. Raimundo RD realizou o recrutamento dos participantes. Silva TD participou da coordenação do protocolo e realizou a análise dos dados. Monteiro CBM e Galhardoni R participaram da organização do resumo e da supervisão da versão final.

\section{Conflitos de interesses}

Nenhum conflito financeiro, legal ou político envolvendo terceiros (governo, empresas e fundações privadas, etc.) foi declarado para nenhum aspecto do trabalho submetido (incluindo, mas não se limitando a subvenções e financiamentos, participação em conselho consultivo, desenho de estudo, preparação de manuscrito, análise estatística, etc.).

\section{Referências}

1. Gallagher DA, Schapira AH. Etiopathogenesis and treatment of Parkinson's disease. Curr Top Med Chem. 2009;9(10):860-8. Citado em: PMID: 19754402

2. Nitsche MA, Liebetanz D, Lang N, Antal A, Tergau F, Paulus W. Safety criteria for transcranial direct current stimulation (tDCS) in humans. Clin Neurophysiol. 2003;114(11):2220-2. https://doi. org/10.1016/s1388-2457(03)00235-9

3. Barbosa RTA, Oliveira ASB, Antão JYFL, Crocetta TB, Guarnieri R, Antunes TPC, et al. Augmentative and alternative communication in children with Down's syndrome: a systematic review. BMC Pediatr. 2018;18(1):160. https://doi.org/10.1186/s12887-018-1144-5

4. Conceição NR. Estimulação transcraniana por corrente contínua durante o exercício aeróbio na doença de Parkinson: efeitos agudos na atividade cortical, cognição e andar [dissertação] [Internet]. Rio Claro: Universidade Estadual Paulista "Júlia de Mesquita Filho"; 2019. Disponível em: http://hdl.handle. $\underline{\text { net/11449/183257 }}$ 